\title{
Andosolization of Soils on a Strombolian Cone at Mount Bambouto, Cameroon
}

\author{
Pierre S. Tsopjio Jiomeneck ${ }^{1}$, Paul Tematio ${ }^{1 *}$, Mike A. Wilson ${ }^{2}$, Martin Yemefack ${ }^{3}$ \\ ${ }^{1}$ Department of Earth sciences, University of Dschang, Dschang, Cameroon; ${ }^{2}$ USDA-Natural Resources Conservation Service, Na- \\ tional Soil Survey Center, Lincoln, USA; ${ }^{3}$ Institut de Recherche Agronomique pour le Développement (IRAD), Yaoundé, Cameroun. \\ Email: *paul_tematio@yahoo.fr
}

Received June 26 ${ }^{\text {th }}, 2011$; revised August $30^{\text {th }}, 2011$; accepted September $10^{\text {th }}, 2011$.

\begin{abstract}
Morphology, mineral and geochemical investigations were carried out on two selected soil pedons (ZA and TO) developed on a late Quaternary-aged strombolian cone to better understand andosolization processes in Mount Bambouto, Cameroon. Both pedons have A-BC-C horizonation. They have thick surface $(A)$ horizon with bulk density $<0.7 \mathrm{~g} \cdot \mathrm{cm}^{-3}$, $\mathrm{Al}_{o}+0.5 \mathrm{Fe}_{0}$ about $2 \%$ and $P$ retention $>90 \%$. Mineral association consists predominantly of kaolinite, gibbsite, goethite, organometal complexes and trace amount of ferrihydrite and allophane. The Ki values between 1.1 and 1.6, the low TRB (45 to $67 \mathrm{mg} \cdot \mathrm{kg}^{-1}$ ), the important IMob (20\% to 24\%), the CIA between $60 \%$ and $70 \%$ and the EFs above 1.16 for $\mathrm{Al}$ and $\mathrm{Fe}$, and below 0.6 for Si indicate sparingly hydrolysis process in subsoil during which released Al, Fe and Si form allophanic or ferrihydrite minerals undergo crystallization into kaolinite, gibbsite and goethite, respectively. At topsoil, part of released $\mathrm{Al}$ (and $\mathrm{Fe}$ ) is organically bounded with organic acids to form organometal complexes.
\end{abstract}

Keywords: Soil Morphology, Mineralogy, Geochemistry, Andosolization, Strombolian Cone, Cameroon Volcanic Line

\section{Introduction}

The Cameroon Volcanic Line extends $1600 \mathrm{~km}$ from the Gulf of Guinea (island of Pagalu) into western Cameroon. Volcanic activity principally ranged from Tertiary to Quaternary in age, but is still on-going [1,2]. Mount Bambouto is a strato-volcano with a well-preserved collapse caldera that has developed from multiple volcanic events initiating with thick basalt lava flow sequences, followed by an eruption with trachytic (fine-grained alkali intermediate igneous rocks) lava flows, with other subsequent volcanic eruptions $[1,3]$. These volcanic deposits cover an area of about $500 \mathrm{~km}^{2}$ intensely used for annual crops and vegetable production. Soil survey of Mount Bambouto, documented soils with andic properties [4] above $1700 \mathrm{~m}$ asl that are formed under a wet, humid climate. Several studies related to pedogenesis have been conducted on soils developed from both trachytes [5,6] and basaltic rocks [7] dated between 16 and $4.5 \mathrm{Ma}[1,3,8]$. These studies showed that Andosols occur on both parent materials.

The andosolization process involves the rapid weathering of fine-grained parent rocks containing glass and microlites under humid conditions. In old trachytes and basaltic rocks from Mount Bambouto, this weathering commonly results in the formation of stable organometal complexes at the soil surface [6]. They are thus non allophanic Andosols and classify as Aluandic Andosols (leptic) based on the WRB system of soil classification [4]. Shoji et al. [9] reported that non allophanic Andosols show very strong acidity ( $\mathrm{pH}<5.0$ ), high $\mathrm{Al}$ saturation and subsequent toxicity of $\mathrm{Al}$ to plants. They have horizons with $\mathrm{Si}_{0}$ less than $0.6 \%, \mathrm{Al}_{\mathrm{p}} / \mathrm{Al}_{\mathrm{o}}$ ratio above 0.5 in the top horizon and phosphorus retention more than $70 \%$. The major occurrences of Andosols in Africa are found in the Rift valley, in Kenya, Rwanda and Ethiopia and in Madagascar [10]. In Cameroon, they occur around Mount Cameroon stretching through the Bakossi area (Mount Manengouba) to Loum and Nkongsamba areas, in Foumbot and in Mount Bambouto (West region), in Wum (North West region), and in the Adamawa plateau [11,12].

However, a recent geological review of Mount Bambouto reported the presence of a strombolian cone made of late quaternary (Middle Pleistocene) basaltic clasts on the NE slope of this mountain that dated around $0.480 \pm$ $0.014 \mathrm{Ma}$ [13]. This finding brought up a question about the andosolization process in Mount Bambouto, and the source of $\mathrm{Al}$ (and $\mathrm{Fe}$ ) involved in the formation of organometal complexes in topsoil is also questioned. Al- 
though it is well-known that the physico-chemical composition of the parent rock is one of the main factor controlling andosolization, Tematio et al. [6] mentioned that $\mathrm{Al}$ and $\mathrm{Fe}$ involved in organometal complexes in Mount Bambouto may originate from partial hydrolysis of secondary minerals (halloysite and iron oxides) due to high microbial activities [14] with liberation of metals which bond to organic acids [15]. This explanation is proved to be acceptable for soils derived from old trachyte [15]. This is what motivated the current research on morpho-chemical characterization of soils derived from the recent strombolian cone. The objectives of the study were thus to: 1) evaluate and quantify the andosolization mechanism prevailing on recent strombolian cone in Mount Bambouto by identifying the source of $\mathrm{Fe}$ and $\mathrm{Al}$ involved in the process; and 2) assess the weathering process and intensity operating in this environment as compared to andosolization process on ancient trachytic lava flows.

\section{Materials and Methods}

\subsection{The Site Setting}

Mount Bambouto is one of the major volcanic mountains in the Cameroon volcanic line that crosses the western part of the area. It is made up of various volcanic products grouped into basic (alkali basalt, basanite, mugearite, hawaïte) and highly differentiated (trachyte, phonolite, rhyolite, ignimbrite) rocks [1-3]. A recent geological review [13] reports a late quaternary (Middle Pleistocene) strombolian cone in the NE slope of Mount Bambouto (Figure 1). This strombolian cone consists of basaltic clasts with hyalo-microlitic and porphyritic texture. Mineral paragenesis is spinel, olivine, Ti-magnetite, clinopyroxene, plagioclase, leucite and interstitial glass with nepheline to sodic plagioclase composition. According to their silica $\left(\mathrm{SiO}_{2}\right.$ : 41.9\% - 43.3\%) and alkaline (MgO: $12.4 \%$ - 12.7\%; $\mathrm{CaO}$ : $10.5 \%-11.4 \% ; \mathrm{Na}_{2} \mathrm{O}: 2.1 \%-3.0 \%$ and $\mathrm{K}_{2} \mathrm{O}: 0.9 \%-$ $1.2 \%)$ contents, and their normative composition $(6.3<$ nepheline $\mathrm{w} \%<10.7 ; 24.2<$ olivine $\mathrm{w} \%<24.8$ ), they belong to basanite from sodic series [13].

The NE slope of Mount Bambouto is characterized by wet, humid and cool climate with perudic moisture regime (1700 to $1800 \mathrm{~mm}$ annual rainfall) and isothermic conditions $\left(15^{\circ} \mathrm{C}\right.$ to $18^{\circ} \mathrm{C}$ mean annual temperature). The rainy season stretches from March to October and the drying season from November to February. The land use in this area consists of annual row cropping with rotational farming of maize, bean, potatoes, etc.

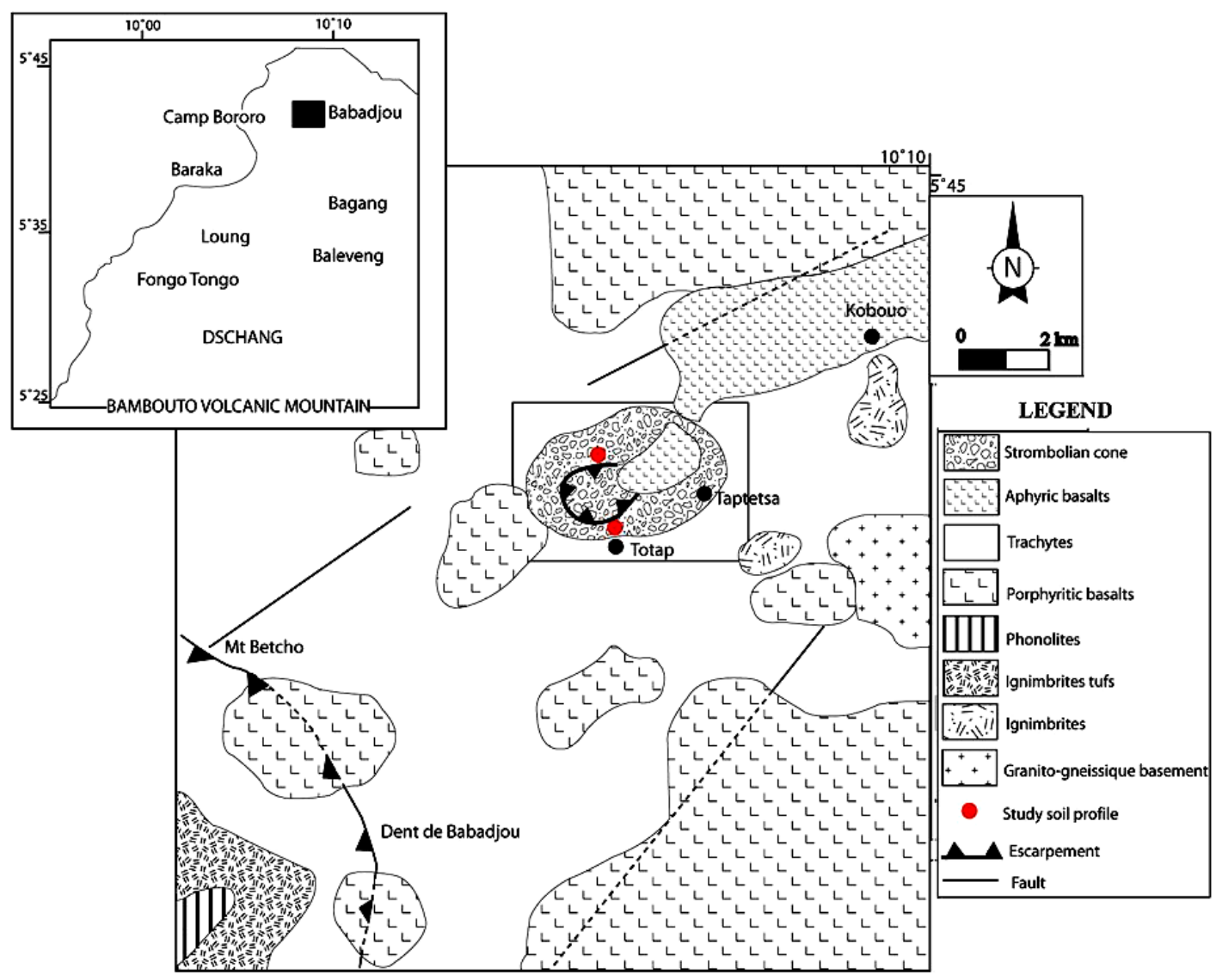

Figure 1. Geological scheme of the study area. 


\subsection{Methods}

Two soil profiles were selected for the study on the late quaternary-aged deposits: the ZA pedon located at an elevation of $1925 \mathrm{~m}$ asl in the northern slope of the cone, and the TO pedon at $2005 \mathrm{~m}$ asl in the southern slope of the cone (Figure 1). Soil profiles were exposed by hand dug pedons through the soil and into the unweathered parent material. Profiles were differentiated by horizon and a morphological description was made [16], consisting of soil color, texture, structure, consistence, and horizon boundary. In each profile, soil samples were collected in triplicate along the thickness of each horizon and mixed to obtain a mean sample. Samples were air-dried, crushed (for saprolite samples), and sieved to the $<2 \mathrm{~mm}$ fraction prior to physical, mineral and chemical analyses.

Previously, the bulk density (BD) is obtained by the cylinder method using $\mathrm{BD}=w / v$ formula where $w$ is the weigh of soil contained in the cylinder and $v$ its volume. Particle size was performed by the Robinson pipette method with $\mathrm{Na}$ hexametaphosphate as dispersal agent. Organic matter is previously oxidized using di-ionized water $\left(\mathrm{H}_{2} \mathrm{O}_{2}\right)$. Organic carbon $(\mathrm{OC})$ is obtained by oxidation using potassium dichromate as oxidizing agent. The available $\mathrm{P}$ is extracted by the combination of $\mathrm{HCl}$ and $\mathrm{NaF}$, and quantified using ammonium molybdate with ascorbic acid as reducing agent. $\mathrm{CEC}$ and exchangeable cations are extracted by ammonium acetate $\left(\mathrm{CHOONH}_{4}\right)$ at $\mathrm{pH} 7$ and quantified using atomic adsorption spectrometer (AA spectrometer). P retention was performed by colorimetry with nitric acid reagent, and quantified by spectrophotometer.

$\mathrm{X}$-ray diffraction (XRD) was performed in finely ground samples using a Rigaku Geigerflex X-ray diffractometer operating at $40 \mathrm{kV}$ and $45 \mathrm{~mA}$ with a Dmax-B controller and $\mathrm{Cu} \mathrm{K} \alpha$ radiation. Samples were analyzed from $3^{\circ}$ to $75^{\circ} 2 \theta$, at $1^{\circ} 2 \theta / \mathrm{min}$. Relative amounts of minerals were assessed using peak height above background assuming that intensity (counts/s) of the highest peak of a mineral corresponds to $100 \%$ of this mineral in the sample. Selective dissolutions [17] were performed using acid ammonium oxalate, dithionite-citrate (DC) and Na pyrophosphate, identified here by the subscripts "o", " $\mathrm{d}$ " and "p", respectively. Extractable $\mathrm{Si}, \mathrm{Al}$ and $\mathrm{Fe}$ were quantified by plasma emission spectroscopy using a JY24 ICPOES spectrometer. Allophane was estimated by $7.1 \times \mathrm{Si}_{\mathrm{o}}$ [18]. Ferrihydrite was estimated by $1.7 \times \mathrm{Fe}_{\mathrm{o}}[19]$ and goethite by $\left[1.6 \times\left(\mathrm{Fe}_{\mathrm{d}}-\mathrm{Fe}_{\mathrm{o}}\right)\right][20]$.

Elemental analysis of the soil was performed following dissolution of the material in concentrated $\mathrm{HNO}_{3}, \mathrm{HCl}$ and $\mathrm{HF}$ acids. Selected elements $\mathrm{Si}, \mathrm{Al}, \mathrm{Fe}, \mathrm{Ti}, \mathrm{Ca}, \mathrm{Mg}$, $\mathrm{K}, \mathrm{Na}, \mathrm{Mn}, \mathrm{P}$ ) were quantified by inductively-coupled plasma spectrometry (ICP-AES). Mass content of each analysed element is reported on a percent oxide basis. En- richment factor (EF) was estimated by the ratio between content of an element in soil material and that of the fresh rock according to the relation $\mathrm{EF}(\mathrm{X})=(\mathrm{Xi} / \mathrm{Ri}) /(\mathrm{Xs} / \mathrm{Rs})[21]$, in which $\mathrm{Xi}$ and $\mathrm{Ri}$ are the concentrations of the element of interest and a reference element (Ri) in a given horizon and Xs and Rs are the concentrations of the same elements in the rock. The total reserve in bases $(T R B)$ represents the sum of base cations $(\mathrm{Ca}+\mathrm{Mg}+\mathrm{K}+\mathrm{Na})$ from the total analysis, expressed as $\mathrm{mg} \cdot \mathrm{kg}^{-1}$ of soil [22]. The chemical index of alteration $(\mathrm{CIA})$ corresponds to $\left[\mathrm{Al}_{2} \mathrm{O}_{3} /\right.$ $\left.\left(\mathrm{Al}_{2} \mathrm{O}_{3}+\mathrm{CaO}^{*}+\mathrm{Na}_{2} \mathrm{O}+\mathrm{K}_{2} \mathrm{O}\right)\right] \times 100$, where $\mathrm{CaO}^{*}$ is the amount of $\mathrm{CaO}$ incorporated in the silicate fraction of fresh rock while $\mathrm{Na}_{2} \mathrm{O}, \mathrm{K}_{2} \mathrm{O}$ and $\mathrm{Al}_{2} \mathrm{O}_{3}$ are their concentrations in the analysed soil samples [23]. The mobility index of element $(I M o b)$ is $\left[\left(M o b_{\text {rock }}-M o b_{\text {soil }}\right) /\left(M o b_{\text {soil }}\right)\right]$ $\times 100$ with $\mathrm{Mob}$ equal to $\left(\mathrm{K}_{2} \mathrm{O}+\mathrm{CaO}+\mathrm{Na}_{2} \mathrm{O}\right)$ [24].

\section{Results}

\subsection{Soil Morphology}

The two soil pedons (ZA and TO) (Figure 2) have relatively shallow, weathered (A-BC-C) profiles with thick surface horizons (Table 1). In ZA pedon, the A horizon is $52 \mathrm{~cm}$ thick and consists of very dark grey (5YR3/1) silty clay, with fine to very fine crumb structure, and friable to very friable consistence. Its lower boundary is diffuse and irregular. It grades to the underlying brighter colored BC horizon. This BC horizon consists of light yellow brown $(2.5 \mathrm{Y} 6 / 4)$ weathered saprolite fragments
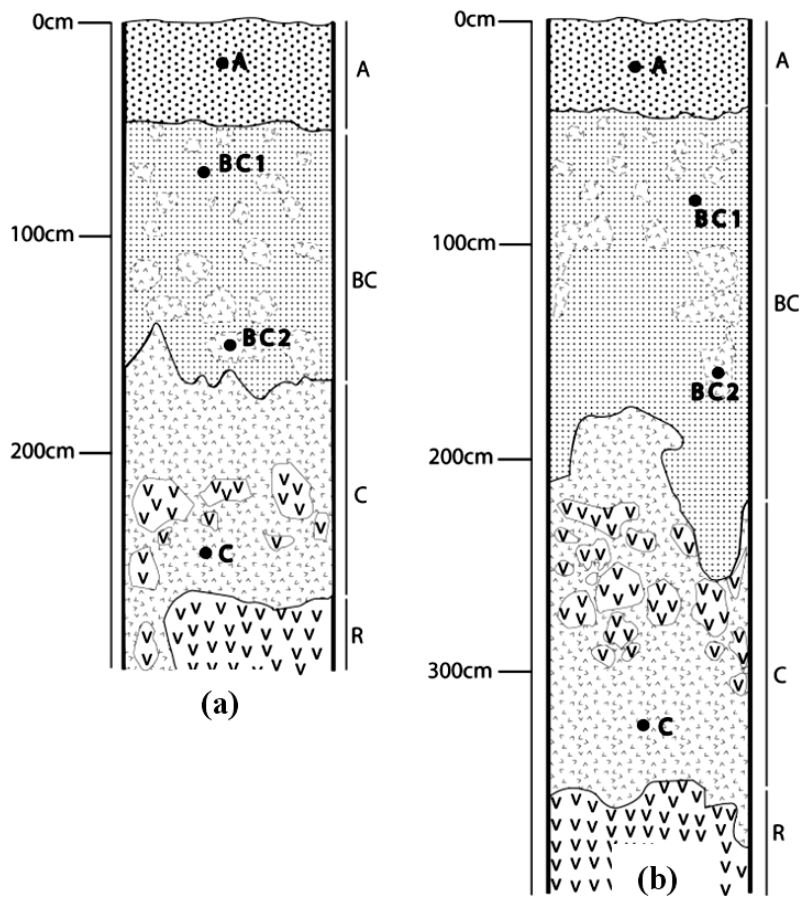

Figure 2. Morphological representation of: (a) ZA; and (b) TO soil pedons. 
Table 1. Morphological characteristics of the selected pedons.

\begin{tabular}{|c|c|c|c|c|c|c|c|c|c|}
\hline Pedon & Horizon & Samples & Depth (cm) & Color & $\begin{array}{l}\text { Textural } \\
\text { classes }\end{array}$ & Structure & Consistence & Lower boundary & $\begin{array}{c}\text { Rock fragments } \\
\text { (size and volumetric } \\
\text { percentage) }\end{array}$ \\
\hline \multirow{4}{*}{ ZA pedon } & A & A & $0-52$ & 5YR3/1 & $\mathrm{sc}$ & $\begin{array}{l}\text { very fine } \\
\text { crumble }\end{array}$ & $\begin{array}{c}\text { friable to } \\
\text { very friable }\end{array}$ & $\begin{array}{c}\text { diffuse and } \\
\text { irregular }\end{array}$ & - \\
\hline & \multirow{2}{*}{$\mathrm{BC}$} & $\mathrm{BC} 1$ & \multirow{2}{*}{$52-160$} & 7.5YR4/4 & $\mathrm{sc}$ & granular & firm & \multirow{2}{*}{$\begin{array}{l}\text { distinct and } \\
\text { abrupt }\end{array}$} & - \\
\hline & & $\mathrm{BC} 2$ & & $2.5 \mathrm{Y} 6 / 4$ & $\mathrm{sc}$ & massive & - & & $\begin{array}{c}5 \mathrm{~cm}-20 \mathrm{~cm} \\
2 \%-20 \%\end{array}$ \\
\hline & $\mathrm{C}$ & $\mathrm{C}$ & $160-260$ & $\begin{array}{c}7.5 \mathrm{YR} 7 / 4 \text { to } \\
2.5 \mathrm{Y} 6 / 2\end{array}$ & ss & massive & - & - & - \\
\hline \multirow{4}{*}{ TO pedon } & A & A & $0-44$ & $5 \mathrm{YR} 3 / 4$ & $\mathrm{sc}$ & $\begin{array}{l}\text { fine to coarse } \\
\text { crumble }\end{array}$ & very friable & $\begin{array}{l}\text { diffuse and } \\
\text { irregular }\end{array}$ & - \\
\hline & \multirow{2}{*}{$\mathrm{BC}$} & $\mathrm{BC} 1$ & \multirow{2}{*}{$44-206$} & 7.5YR4/4 & ss & fine granular & firm & \multirow{2}{*}{$\begin{array}{c}\text { distinct and } \\
\text { abrupt }\end{array}$} & - \\
\hline & & $\mathrm{BC} 2$ & & $\begin{array}{l}10 \mathrm{YR} 5 / 3 \\
2.5 \mathrm{Y} 6 / 2\end{array}$ & $\mathrm{ss}^{*}$ & massive & - & & $\begin{array}{c}5 \mathrm{~cm}-25 \mathrm{~cm} \\
5 \%-20 \%\end{array}$ \\
\hline & $\mathrm{C}$ & $\mathrm{C}$ & $206-360$ & $10 \mathrm{YR} 5 / 3$ & $\mathrm{ss}^{*}$ & massive & - & - & - \\
\hline
\end{tabular}

Textural classes: sc, silty clay; ss, silty sand; ss ${ }^{*}$, sandy silt.

with micrometric and polychromatic punctuations embedded in a dark brown (7.5YR4/4) silty clay soil matrix. It has fine granular soil structure with firm consistence. There are also a few unweathered pyroclastic fragments. With depth, weathered saprolite fragments become bigger and form a continuous $\mathrm{C}$ horizon below $2.0 \mathrm{~m}$.

The boundary of the $\mathrm{BC}$ horizon with the underlying C-horizon is distinct, with an abrupt, wavy boundary. This C horizon consists of pink (7.5YR7/4) to light brown grey $(2.5 \mathrm{Y} 6 / 2)$ silty sand weathered materials with micrometric and polychromatic punctuations.

Pedon TO is $3.6 \mathrm{~m}$ deep. The A horizon is $44 \mathrm{~cm}$ thick, dark brown (5YR3/4) colored, silty clay texture with fine to coarse crumb structure and very friable consistence. Its transition to the underlying brighter colored $\mathrm{BC}$ horizon is gradual, with a diffuse and irregular boundary.

The fine earth of $\mathrm{BC}$ horizon is dark brown (7.5YR4/4), silty sand texture with fine granular structure and firm consistence. It has weathered saprolite fragments that are light brown (10YR5/3) and break down into a sandy silt texture, and few light brownish grey (2.5Y6/2) unweathered pyroclastic fragments. With depth, the weathered saprolite and unweathered pyroclastic fragments increase in number and size and demarcate an almost continuous $\mathrm{C}$ horizon at about $1.5 \mathrm{~m}$ depth. The transition to the underlying $\mathrm{C}$ horizon is distinct, with an abrupt and irregular boundary.

\subsection{Physico-Chemical Soil Properties}

The bulk density (Table 2) is very low $\left(<0.82 \mathrm{~g} \cdot \mathrm{cm}^{-3}\right)$ throughout the profiles of both soils, with values of 0.65 $\mathrm{g} \cdot \mathrm{cm}^{-3}$ and $0.67 \mathrm{~g} \cdot \mathrm{cm}^{-3}$ in surface horizons of pedons ZA and TO, respectively, and increasing slightly with depth. Particle size indicates moderate proportion of sand at the soil surface $(\approx 35 \%)$ which increases up to about $75 \%$ with depth. Inversely, the amount of clay is high at soil surface (39\% and $29 \%$, for pedons ZA and TO, respectively) and decreases significantly in the $\mathrm{C}$ horizons $(<8 \%)$. The amount of silt also decreases slightly with depth.

The soils ranges from highly-acid to acid, with $\mathrm{pH}$ ranging from 4.3 to 5.3 in pedon ZA and 3.9 to 4.7 in pedon TO. The organic carbon is very high in the surface horizon ( $7.0 \%$ and $5.9 \%$ in pedons ZA and TO, respectively). The available $\mathrm{P}$ is also relatively high at soil surface (11 $\mathrm{mg} \cdot \mathrm{kg}^{-1}$ and $7 \mathrm{mg} \cdot \mathrm{kg}^{-1}$ in pedons ZA and TO, respectively). The sum of exchangeable cations is low (less than $12 \mathrm{cmol} \cdot \mathrm{kg}^{-1}$ ), with its highest values deeper in the profile. The most abundant exchangeable cations are $\mathrm{Mg}^{2+}$ $\left(\leq 7.7 \mathrm{cmol} \cdot \mathrm{kg}^{-1}\right)$ and $\mathrm{Ca}^{2+}\left(\leq 3.2 \mathrm{cmol} \cdot \mathrm{kg}^{-1}\right)$. Inversely, the CEC is relatively high ( 19.6 to $28.9 \mathrm{cmol} \cdot \mathrm{kg}^{-1}$ in pedon ZA and 20.1 to $25.4 \mathrm{cmol} \cdot \mathrm{kg}^{-1}$ in pedon TO). The exchangeable $\mathrm{Al}^{3+}$ is relatively low in pedon $\mathrm{ZA}$, but ranges up to $11.3 \mathrm{cmol} \cdot \mathrm{kg}^{-1}$ in pedon TO. The P retention is very high, $>90 \%$ in the upper part of both soils. The acid ammonium oxalate extractable $\mathrm{Al}_{\mathrm{o}}+0.5 \mathrm{Fe}_{\mathrm{o}}$ is about $2 \%$ at soil surface, but decreases with depth.

\subsection{Soil Mineralogy}

In general, mineral associations in the studied soils correspond to kaolinite, gibbsite, goethite, ferrihydrite, allophane and organometal complexes. However, primary minerals like plagioclase and pyroxene are still present in specific materials. Both soils contain a large amount of organometal complexes (Tables $\mathbf{3}$ and $\mathbf{4}$ ) as well as shortrange and long-range ordered minerals. There are also not completely weathered primary minerals remaining in these soils.

The primary minerals: Primary minerals include plagioclase and pyroxene (Figure 3). In pedon ZA, plagioclase 
Table 2. Physical and chemical soil properties of the selected pedons.

\begin{tabular}{|c|c|c|c|c|c|c|c|c|c|c|c|c|c|c|c|c|c|c|}
\hline \multirow{2}{*}{$\begin{array}{l}\text { Studied } \\
\text { pedon }\end{array}$} & \multirow{2}{*}{ Soil horizon } & \multirow{2}{*}{ samples } & \multirow{2}{*}{$\begin{array}{c}\mathrm{BD} \\
\left(\mathrm{g} \cdot \mathrm{cm}^{-3}\right)\end{array}$} & \multicolumn{4}{|c|}{$\begin{array}{c}\text { Particle size } \\
(\%)\end{array}$} & \multicolumn{2}{|c|}{ Organic matter } & \multicolumn{6}{|c|}{$\begin{array}{l}\text { Exchangeable cations } \\
\left(\mathrm{cmol} \cdot \mathrm{kg}^{-1}\right)\end{array}$} & \multirow{2}{*}{$\begin{array}{c}\mathrm{CEC} \\
\left(\mathrm{cmol} \cdot \mathrm{kg}^{-1}\right)\end{array}$} & \multirow{2}{*}{$\begin{array}{l}\mathrm{P} \text { retention } \mathrm{Al}_{\mathrm{o}} \\
\quad(\%)\end{array}$} & \multirow{2}{*}{$\begin{array}{l}+0.5 \mathrm{Fe}_{\mathrm{o}} \\
(\%)\end{array}$} \\
\hline & & & & clay & silt & sand & $\mathrm{pHw}$ & $\mathrm{OC}(\%)$ & $\begin{array}{c}\text { available P } \\
\left(\mathrm{mg} \cdot \mathrm{kg}^{-1}\right)\end{array}$ & $\mathrm{Ca}^{2+}$ & $\mathrm{Mg}^{2+}$ & $\mathrm{K}^{+}$ & $\mathrm{Na}^{+}$ & $\mathrm{S}$ & $\mathrm{Al}^{3+}$ & & & \\
\hline \multirow{4}{*}{$\begin{array}{c}\mathrm{ZA} \\
\text { pedon }\end{array}$} & $\begin{array}{c}\mathrm{A} \\
(0-52 \mathrm{~cm})\end{array}$ & A & 0.65 & 31 & 31 & 38 & 4.3 & 7.0 & 11 & 2.2 & 0.8 & 0.1 & 0.0 & 3.1 & 1.5 & 27.1 & 94 & 1.9 \\
\hline & $\mathrm{BC}$ & $\mathrm{BC} 1$ & 0.75 & 39 & 27 & 34 & 4.5 & 0.48 & 1 & 0.3 & 1.2 & 1.0 & 0.0 & 2.5 & 1.5 & 22.2 & 92 & 1.7 \\
\hline & $(52-160 \mathrm{~cm})$ & $\mathrm{BC} 2$ & 0.77 & 38 & 26 & 36 & 5.3 & 0.15 & 0 & 1.1 & 1.8 & 0.4 & 0.0 & 3.3 & 0.5 & 19.6 & 93 & 1.6 \\
\hline & $\begin{array}{c}\mathrm{C} \\
(160-260 \mathrm{~cm})\end{array}$ & $\mathrm{C}$ & 0.81 & 7 & 18 & 75 & 4.9 & 0.0 & 7 & 1.7 & 7.6 & 0.1 & 0.0 & 9.4 & 0.5 & 28.9 & 83 & 1.2 \\
\hline \multirow{3}{*}{$\begin{array}{l}\text { TO } \\
\text { pedon }\end{array}$} & $\begin{array}{c}A \\
(0-44 \mathrm{~cm})\end{array}$ & A & 0.67 & 29 & 38 & 33 & 4.7 & 5.9 & 7 & 2.3 & 1.0 & 0.1 & 0.0 & 3.4 & 4.5 & 25.4 & 95 & 2.2 \\
\hline & $\mathrm{BC}$ & BC1 & 0.66 & 20 & 24 & 56 & 3.9 & 1.1 & 0 & 1.0 & 1.7 & 0.1 & 0.0 & 3.4 & 7.0 & 23.1 & 92 & 1.3 \\
\hline & $\begin{array}{c}C \\
(206-360 \mathrm{~cm})\end{array}$ & $\mathrm{C}$ & 0.72 & 4 & 18 & 78 & 4.4 & 0.0 & 5 & 3.2 & 7.7 & 0.2 & 0.0 & 11.1 & 1.3 & 22.3 & 78 & 1.1 \\
\hline
\end{tabular}

OC: organic carbon; S: sum of exchangeable cations; BD: bulk density.

Table 3. Selective extraction data for selected pedons.

\begin{tabular}{|c|c|c|c|c|c|c|c|c|c|c|c|}
\hline \multirow[b]{2}{*}{ Selected pedon } & \multirow[b]{2}{*}{ Soil horizon } & \multirow[b]{2}{*}{ samples } & Total co & ntration & & & & ve ext & & & \\
\hline & & & \multicolumn{9}{|c|}{ concentrations in $\%$} \\
\hline \multirow{4}{*}{ ZA pedon } & $A(0-52 \mathrm{~cm})$ & A & 11.01 & 13.64 & 1.30 & 8.90 & 1.18 & 1.39 & 1.88 & 0.80 & 1.20 \\
\hline & \multirow{2}{*}{$\mathrm{BC}(52-160 \mathrm{~cm})$} & $\mathrm{BC} 1$ & 12.07 & 13.64 & 1.40 & 9.10 & 0.93 & 1.57 & 1.72 & 0.90 & 0.60 \\
\hline & & $\mathrm{BC} 2$ & 12.01 & 13.78 & 1.00 & 9.0 & 0.72 & 1.71 & 1.58 & 0.30 & 0.40 \\
\hline & $\mathrm{C}(160-260 \mathrm{~cm})$ & $\mathrm{C}$ & 10.43 & 15.32 & 0.50 & 7.50 & 0.50 & 1.37 & 0.69 & 0.10 & - \\
\hline \multirow{4}{*}{ TO pedon } & $\mathrm{A}(0-44 \mathrm{~cm})$ & A & 10.58 & 13.50 & 1.30 & 8.40 & 1.31 & 1.68 & 2.15 & 0.80 & 0.60 \\
\hline & \multirow{2}{*}{$\mathrm{BC}(44-206 \mathrm{~cm})$} & $\mathrm{BC} 1$ & 11.85 & 13.15 & 0.90 & 7.90 & 0.69 & 1.26 & 1.32 & 0.30 & 0.30 \\
\hline & & $\mathrm{BC} 2$ & 11.59 & 9.72 & 0.50 & 4.10 & 0.48 & 0.62 & 0.79 & 0.20 & - \\
\hline & $\mathrm{C}(206-360 \mathrm{~cm})$ & $\mathrm{C}$ & 10.74 & 13.57 & 0.40 & 7.70 & 0.42 & 1.25 & 1.07 & 0.10 & - \\
\hline
\end{tabular}

Table 4. Minerals in the selected pedons.

\begin{tabular}{|c|c|c|c|c|c|c|c|c|c|c|}
\hline \multirow{3}{*}{ Pedon } & \multirow{3}{*}{ Soil horizon } & \multirow{3}{*}{ samples } & \multicolumn{4}{|c|}{ Minerals detected by XRD } & \multicolumn{4}{|c|}{ Minerals estimated by selective extraction } \\
\hline & & & \multicolumn{8}{|c|}{ abundance in \% } \\
\hline & & & kaolinite & gibbsite & plagioclase & pyroxene & goethite & ferrihydrite & allophane & $\begin{array}{c}\text { Organo-metal } \\
\text { complexes }\end{array}$ \\
\hline \multirow{4}{*}{ ZA pedon } & $\mathrm{A}(0-52 \mathrm{~cm})$ & A & 71 & 12 & 0 & - & 12 & 2.4 & 1.1 & 2.1 \\
\hline & \multirow{2}{*}{$\mathrm{BC}(52-160 \mathrm{~cm})$} & $\mathrm{BC} 1$ & 57 & 26 & 0 & - & 12 & 2.7 & 0.6 & 0.9 \\
\hline & & $\mathrm{BC} 2$ & 54 & 29 & 0 & - & 12 & 2.9 & 0.9 & 0.7 \\
\hline & $C(160-260 \mathrm{~cm})$ & $\mathrm{C}$ & 60 & 13 & 14 & - & 10 & 2.3 & 1.1 & 0.1 \\
\hline \multirow{4}{*}{ TO pedon } & $\mathrm{A}(0-44 \mathrm{~cm})$ & A & 75 & 9 & 0 & 0 & 11 & 2.9 & 1.1 & 1.4 \\
\hline & \multirow{2}{*}{$\mathrm{BC}(44-206 \mathrm{~cm})$} & $\mathrm{BC} 1$ & 29 & 19 & 23 & 0 & 11 & 2.1 & 0.7 & 0.6 \\
\hline & & $\mathrm{BC} 2$ & 3 & 3 & 64 & 23 & 6 & 1.1 & 0.6 & 0.2 \\
\hline & $C(206-360 \mathrm{~cm})$ & $\mathrm{C}$ & 29 & 0 & 57 & 0 & 10 & 2.1 & 0.9 & 0.1 \\
\hline
\end{tabular}



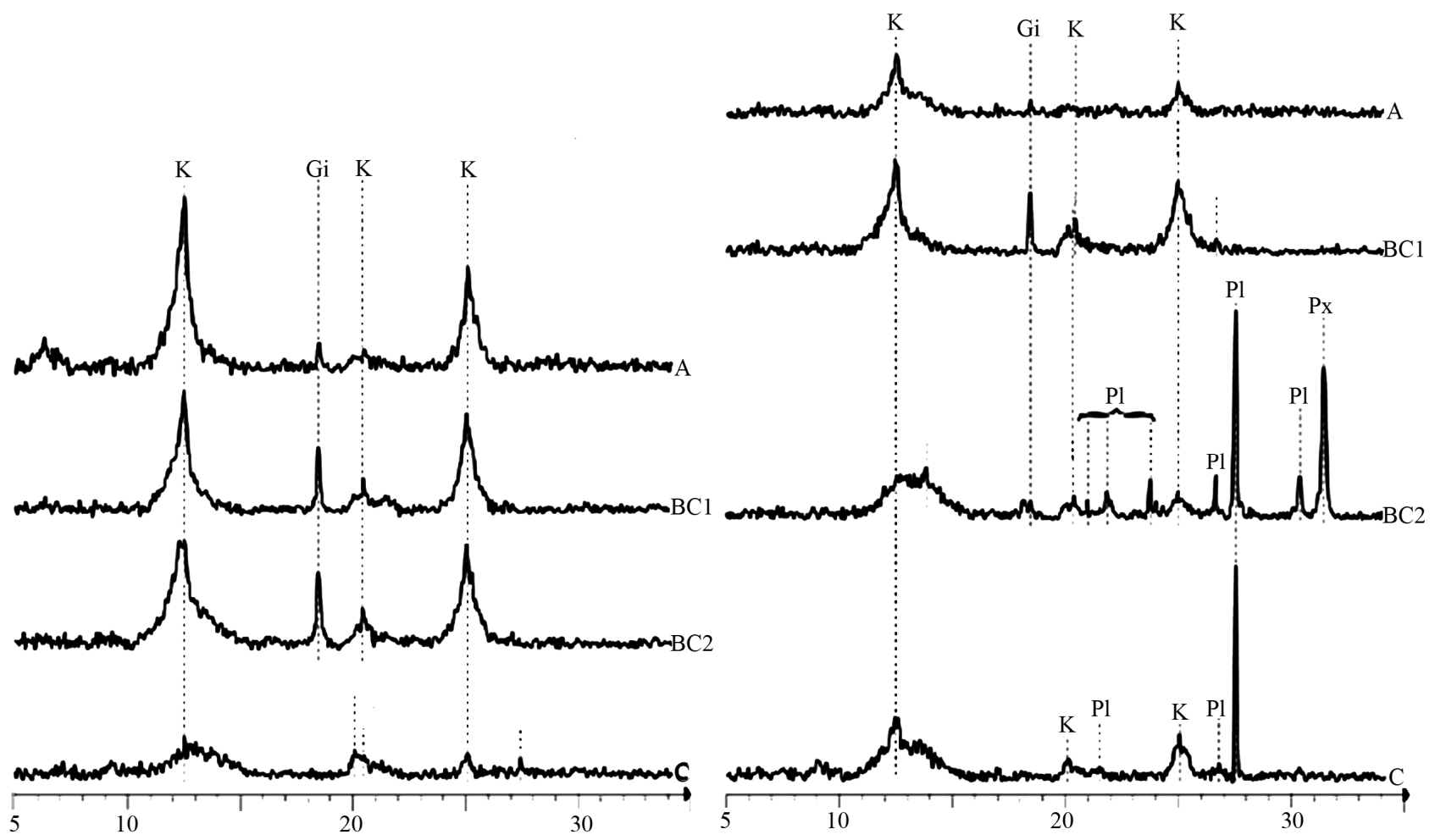

K: kaolinite; Gi: gibbsite; Pl: plagioclase; Px: pyroxene

Figure 3. X-ray patterns of the studied soil pedons.

is the remaining primary mineral in weathered saprolite (C horizon) and represents $14 \%$ of the minerals (Table 4). Plagioclase and pyroxene are present in pedon TO. Plagioclase displays a sharp and intense peak at $0.323 \mathrm{~nm}$ in the weathered rock fragments (Figure 3). In the weathered rock fragments, it represents $57 \%$ to $64 \%$ of the minerals. Peak representing pyroxene is at $0.283 \mathrm{~nm}$ and the weathered saprolite has $23 \%$ of this mineral.

The short-range ordered minerals and the organometal complexes: The organometal complexes correspond to the $\mathrm{Al}$ (and/or Fe)-humus complexes extracted by sodium pyrophosphate (Table 3). These complexes are found in small quantities at soil surface (Table 4).

The short-range ordered minerals identified correspond to allophane and ferrihydrite. Allophane contents are reltively low in both soils (less than 1.2\%) and varied little with depth. Ferrihydrite contents are slightly higher throughout these soils $(2.3 \%$ to $2.9 \%$ in pedon $\mathrm{ZA}$ and 1.1 to $2.9 \%$ in pedon TO) (Table 4).

The long-range ordered minerals: The long-range ordered minerals identified by XRD (Figure 3) are kaolinite and gibbsite, and goethite was quantified by selective extraction (Table 4). Kaolinite has peaks at about 0.715 $\mathrm{nm}$ and $0.357 \mathrm{~nm}$. It is the most abundant secondary mineral in these soils representing $54 \%$ to $71 \%$ and $3 \%$ to
$75 \%$ of the minerals in pedons $\mathrm{ZA}$ and $\mathrm{TO}$, respectively (Table 4). The largest amount of kaolinite is in the topsoil. Gibbsite is also prominent in these soils, with major peak around $0.485 \mathrm{~nm}$. It is the second most abundant secondary mineral in these soils and varies from $12 \%$ to $29 \%$ and 3 to $19 \%$ in pedons ZA and TO, respectively. This mineral is present in largest amounts in the $\mathrm{BC}$ horizons, and decreases in concentration in the $\mathrm{A}$ and $\mathrm{C}$ horizons (Table 4). Goethite is the only iron bearing mineral in these pedons and has a relatively uniform concentration with depth in both pedons. It varies from $10 \%$ to $12 \%$ and $6 \%$ to $11 \%$ in pedons ZA and TO, respectively (Table 4).

\subsection{Soil Geochemistry}

Silica contents (Table 5) decrease from about $43 \%$ in the fresh rock to $28 \%$ in the soil surface. Alkalis $\left(\mathrm{K}_{2} \mathrm{O}\right.$ and $\left.\mathrm{Na}_{2} \mathrm{O}\right)$ and alkaline earth $(\mathrm{CaO}$ and $\mathrm{MgO})$ elements also decrease in soil relative to the fresh rock (Table 5), and remain very low throughout the profiles. Inversely, $\mathrm{Al}_{2} \mathrm{O}_{3}$ and $\mathrm{Fe}_{2} \mathrm{O}_{3}$ contents increase in soil $\left(23 \% \mathrm{Al}_{2} \mathrm{O}_{3} ; 21 \%\right.$ of $)$ relative to the fresh rock (about $12 \% \mathrm{Al}_{2} \mathrm{O}_{3}$ and $13 \%$ $\mathrm{Fe}_{2} \mathrm{O}_{3}$ ). The $\mathrm{Al}_{2} \mathrm{O}_{3}$ contents decrease very slightly at soil surface (about 20\%) while $\mathrm{Fe}_{2} \mathrm{O}_{3}$ did not vary much throughout the profiles.

The molar ratio $\mathrm{Ki}\left(\mathrm{SiO}_{2} / \mathrm{Al}_{2} \mathrm{O}_{3}\right)$, an indicator of the 
Table 5. Major elements abundances and weathering indexes in the selected pedons.

\begin{tabular}{|c|c|c|c|c|c|c|c|c|c|c|c|c|c|c|c|c|}
\hline \multirow{2}{*}{$\begin{array}{l}\text { Studied } \\
\text { pedons }\end{array}$} & \multirow{2}{*}{ Soil horizon } & \multirow{2}{*}{ samples } & \multicolumn{10}{|c|}{ Major elements abundance (\%) } & \multirow[b]{2}{*}{$\mathrm{Ki}$} & \multirow[b]{2}{*}{$\begin{array}{c}\mathrm{TRB} \\
\left(\mathrm{mg} \cdot \mathrm{kg}^{-1}\right)\end{array}$} & \multirow[b]{2}{*}{$\begin{array}{l}\text { CIA } \\
(\%)\end{array}$} & \multirow[b]{2}{*}{$\begin{array}{c}\text { IMob } \\
(\%)\end{array}$} \\
\hline & & & $\mathrm{SiO}_{2}$ & $\mathrm{Al}_{2} \mathrm{O}_{3}$ & $\mathrm{Fe}_{2} \mathrm{O}_{3}$ & $\mathrm{TiO}_{2}$ & $\mathrm{CaO}$ & $\mathrm{MgO}$ & $\mathrm{K}_{2} \mathrm{O}$ & $\mathrm{Na}_{2} \mathrm{O}$ & $\mathrm{MnO}$ & $\mathrm{P}_{2} \mathrm{O}_{5}$ & & & & \\
\hline \multirow{5}{*}{$\begin{array}{c}\mathrm{ZA} \\
\text { pedon }\end{array}$} & $\mathrm{A}(0-52 \mathrm{~cm})$ & $\mathrm{A}$ & 28.1 & 20.8 & 19.5 & 4.0 & 0.2 & 0.7 & 0.4 & 0.2 & 0.3 & 0.4 & 1.4 & 57.6 & 65.4 & 17.2 \\
\hline & \multirow{2}{*}{$\mathrm{BC}(52-160 \mathrm{~cm})$} & $\mathrm{BC} 1$ & 25.4 & 22.8 & 19.5 & 3.9 & 0.1 & 0.6 & 0.3 & 0.2 & 0.2 & 0.4 & 1.1 & 52.4 & 67.6 & 21.4 \\
\hline & & $\mathrm{BC} 2$ & 26.2 & 22.7 & 19.7 & 3.9 & 0.1 & 0.7 & 0.3 & 0.2 & 0.2 & 0.4 & 1.2 & 46.1 & 67.6 & 24.5 \\
\hline & $\mathrm{C}(160-260 \mathrm{~cm})$ & $\mathrm{C}$ & 29.0 & 19.7 & 21.9 & 4.5 & 0.2 & 3.8 & 0.3 & 0.2 & 0.3 & 0.6 & 1.5 & 48.9 & 64.3 & 20.7 \\
\hline & $\mathrm{R}(260 \mathrm{~cm}-)$ & $\mathrm{R}$ & 43.3 & 12.6 & 13.3 & 2.8 & 10.5 & 12.5 & 0.9 & 3.0 & 0.2 & 0.7 & 3.4 & 252.9 & 46.6 & - \\
\hline \multirow{5}{*}{$\begin{array}{c}\mathrm{TO} \\
\text { pedon }\end{array}$} & $\mathrm{A}(0-44 \mathrm{~cm})$ & A & 27.6 & 20.0 & 19.3 & 3.6 & 0.2 & 0.9 & 0.4 & 0.2 & 0.3 & 0.4 & 1.4 & 62.6 & 63.8 & 19.4 \\
\hline & \multirow{2}{*}{ BC $(44-206 \mathrm{~cm})$} & $\mathrm{BC} 1$ & 30.9 & 22.4 & 18.8 & 3.6 & 0.1 & 0.7 & 0.4 & 0.2 & 0.3 & 0.4 & 1.4 & 57.1 & 66.3 & 20.0 \\
\hline & & $\mathrm{BC} 2$ & 39.6 & 21.9 & 13.9 & 2.6 & 0.2 & 0.7 & 1.1 & 0.6 & 0.3 & 0.3 & 1.8 & 66.7 & 63.6 & 6.9 \\
\hline & $\mathrm{C}(206-360 \mathrm{~cm})$ & $\mathrm{C}$ & 32.9 & 20.3 & 19.4 & 4.0 & 0.2 & 14.0 & 0.6 & 0.2 & 0.3 & 0.4 & 1.6 & 101.0 & 63.7 & 14.5 \\
\hline & $\mathrm{R}(360 \mathrm{~cm} \mathrm{-})$ & $\mathrm{R}$ & 42.2 & 12.1 & 13.9 & 2.9 & 10.9 & 12.7 & 1.2 & 2.7 & 0.2 & 0.8 & 3.5 & 170.7 & 45.0 & - \\
\hline
\end{tabular}

$\mathrm{Ki}, \mathrm{SiO}_{2} / \mathrm{Al}_{2} \mathrm{O}_{3}$; TRB, total reserve in bases; CIA, chemical index of alteration; IMob, mobility index.

relative mobility of $\mathrm{Si}$ to $\mathrm{Al}$ (Table 5), decreases in relation to the parent material (from 3.5 to 1.1). The total reserve in base (TRB), a measure gives of the weathered primary minerals in soils, also drops from the fresh rock (252.9 and $170.7 \mathrm{mg} \cdot \mathrm{kg}^{-1}$ in pedons ZA and TO, respecttively) to the weathered level (46.1 and $66.7 \mathrm{mg} \cdot \mathrm{kg}^{-1}$, respectively), suggesting the depletion of weatherable minerals in the topsoil. Inversely, the chemical index of alteration $(C I A)$, representing the weathering intensity, and the mobility index (IMob) used to evaluate the intensity of $\mathrm{CaO}, \mathrm{Na}_{2} \mathrm{O}$ and $\mathrm{K}_{2} \mathrm{O}$ exportation during weathering [24], increase drastically from the fresh rock (46.6 and $45.0 \%$ of $C I A$, in pedons ZA and TO, respectively) to the topsoil, with their highest values in horizon BC $(67 \%$ $C I A, 24.5 \% I M o b)$. This is consistent with a moderately weathering intensity in a highly leaching milieu.

Enrichment-depletion of chemical elements in the studied soils was assessed using enrichment factors (EF). The chemical elements analysed are grouped into enriched (EF $>1.00)$ and depleted $(\mathrm{EF}<1.00)$ elements according to their enrichment factors (Figure 4). Enriched elements are $\mathrm{Al}_{2} \mathrm{O}_{3}$ and $\mathrm{Fe}_{2} \mathrm{O}_{3} \cdot \mathrm{Al}_{2} \mathrm{O}_{3}$ is enriched in both studied pedons, with $\mathrm{EF}$ varying from 1.16 to 1.30 in pedon $\mathrm{ZA}$ and 1.22 to 2.02 in pedon TO. The highest $\mathrm{EFs}$ for $\mathrm{Al}_{2} \mathrm{O}_{3}$ are in the subsurface horizon $\mathrm{BC} . \mathrm{Fe}_{2} \mathrm{O}_{3}$ is slightly enriched in the studied profiles, with EF not exceeding 1.03 in pedon ZA and 1.12 in pedon TO. Depleted elements are $\mathrm{SiO}_{2}, \mathrm{CaO}$, $\mathrm{MgO}, \mathrm{K}_{2} \mathrm{O}$ and $\mathrm{Na}_{2} \mathrm{O} . \mathrm{SiO}_{2}$ is moderately depleted, with EF varied from 0.42 to 0.45 in pedon $\mathrm{ZA}$, and 0.53 to 1.05 in pedon TO. $\mathrm{K}_{2} \mathrm{O}$ also is moderately depleted in the studied profiles (EF from 0.21 to 0.31 in pedons $\mathrm{ZA}$ and 0.27 to 1.02 in pedon TO). But, $\mathrm{CaO}, \mathrm{MgO}$ and $\mathrm{Na}_{2} \mathrm{O}$ are strongly depleted in the studied profiles, with $\mathrm{EF}<0.2$.

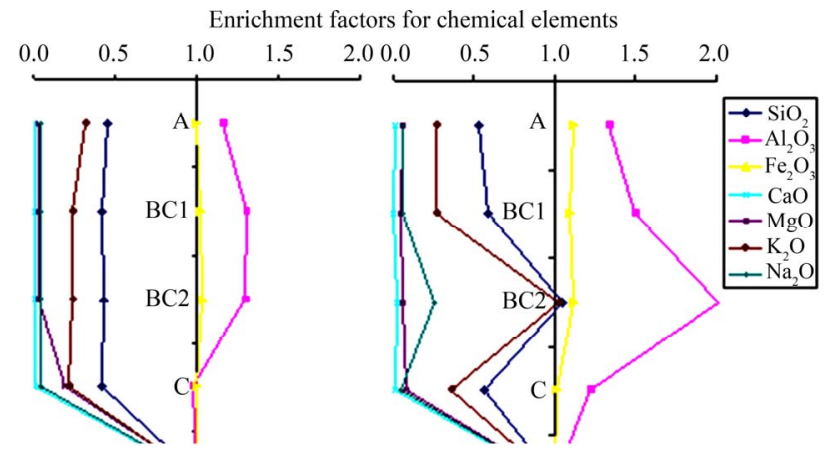

Figure 4. Graphs of chemical element mobility in the studied soil pedons.

\section{Discussion}

The studied soils belong to the reference group of Andosol in the WRB system [4] as indicated by the low bulk density $\left(<0.7 \mathrm{~g} \cdot \mathrm{cm}^{-3}\right)$, Alo $+0.5 \mathrm{Feo}$ about $2 \%$ and the $\mathrm{P}$ retention $\gg 90 \%$ in their surface horizon $\mathrm{A}$. The high organic carbon in the surface horizon A (OC: $5.9 \%$ and $7.0 \%$ ) confirms that the pedogenetic conditions in andic soils favour accumulation of organic matter [25]. They are depleted of bases with the base saturation $<15 \%$ (not shown) which results in the use of the dystric qualifier as suffix for this WRB reference group [4]. The low content of Si extracted by ammonium oxalate (Sio: $0.15 \%$ ) (Table 3) and the Alp/Alo ratio $>0.5$ (0.7 in pedon ZA and 0.6 in pedon $\mathrm{TO}$ ) (not shown) which indicate that $\mathrm{Al}$ is predominantly organically bound [26] suggest that these soils owe their andic properties to Al-humus complexes and therefore belong to the non-allophanic category of andosols. These remarks justify the use of the aluandic quailfier as prefix for this reference group. Therefore, these 
soils key out as aluandic ANDOSOLS (dystric) according to the WRB soil classification system [4].

Referring to the weathering process, kaolinite and goethite are the dominant weathering products in both soil pedons. Their presence in the weathered saprolite is accompanied by the decrease of TRB, the increase of IMob and the EFs far below 0.6 for $\mathrm{Si}, \mathrm{Ca}, \mathrm{Mg}, \mathrm{K}$ and $\mathrm{Na}$. These observations point out an important depletion of silica and total leaching of base cations, highlighting a sparingly hydrolyses [19] in subsoil. Thus, in these soils, weathering leads to faster release of $\mathrm{Al}, \mathrm{Fe}$ and $\mathrm{Si}$ which are initially incorporated into allophanic and ferrihydrite minerals. These short-range ordered minerals are transient and undergo crystallization into poorly crystallized kaolinite and goethite under humid conditions [17,27]. In the topsoil, kaolinite, goethite, gibbsite and organometal complexes are present. Occurrence of gibbsite isolated in the topsoil has been reported in various andosols worldwide [6,28-31]. It was largely attributed to localised desilication of kaolinitic minerals during intense leaching in highly acid milieu under perudic conditions. Also, the topsoil is strong acidic $(\mathrm{pH}<4.7)$, enhancing the formation of organometal complexes [32] and accumulation of organic matter which limit precipitation of $\mathrm{Al}$ and $\mathrm{Si}$ [33], and result in anti-allophanic effect [9]. In fact, below pH 4.9, $\mathrm{Al}$ is in a monomeric or organically complexed form and is not available for incorporation into mineral structure [9]. About the weathering intensity, the CIA between 60 and $70 \%$ and the abundance of secondary minerals indicate that the weathering gradient of these soils is moderately high [34]. This is emphasized by the absence of weatherable primary minerals at soil surface (low TRB), which attests that the fresh rock has been completely weathered.

From findings, a major difference in the andosolization process operating on old trachytic formations from those operating on recent strombolian deposits is the formation of kaolinite instead of halloysite in the late quaternary strombolian cone soils. This may be consistent with the less humid conditions prevailing in the NE slope of Mount Bambouto, highly influenced by relatively dry wind from Sahara desert named Harmattan [35]. Except the above difference, both Andosols in Mount Bambouto show similar morphology (shallow weathered A-BC-C soil pedons) and approximately the same mineral composition (organometal complexes, $\mathrm{Al}$ bearing 1:1 clay minerals, gibbsite and goethite). Consequently, the similar weathering processes are likely operating in both sites at Mount Bambouto, and therefore, the discontinuities of the volcanic activities (rocks age) of these sites have little influence.

\section{Conclusions}

In the late quaternary strombolian deposits from Mount
Bambouto, andic soils refer to aluandic ANDOSOLS (dystric). They derive from the andosolization process which corresponds to fast and intense release of $\mathrm{Si}, \mathrm{Al}$ and $\mathrm{Fe}$ during rapid hydrolysis of volcanic products under humid conditions. Transient allophanic and ferrihydrite minerals are formed that crystallized into kaolinite, gibbsite and goethite. Part of released $\mathrm{Al}$ (and Fe) is bounded at topsoil by organic acids to form stable and less mobile organometal complexes. Thus in Mount Bambouto, andosols are non-allophanic which seem to have developed at the same period despite the wide range of rock ages and type.

\section{REFERENCES}

[1] A. Marzoli, E. M. Piccirillo, P. R. Renne, G. Bellieni, M. Iacumin, J. B. Nyobe and A. T. Tongwa, "The Cameroon Volcanic Line Revisited: Petrogenesis of Continental Basaltic Magmas from Lithospheric and Asthenospheric Mantle Source," Journal of Petrology, Vol. 41, No. 1, 2000, pp. 87-109. doi:10.1093/petrology/41.1.87

[2] A. Nono, E. Njonfang, A. K. Dongmo, D. G. Nkouathio and F. M. Tchoua, "Pyroclastic Deposits of the Bambouto Volcano (Cameroon Line, Central Africa): Evidence of an Initial Strombolian Phase," Journal of African Earth Science. Vol. 39, No. 3-5, 2004, pp. 409-414.

doi:10.1016/j.jafrearsci.2004.07.026

[3] A. Marzoli, P. R. Renne, E. M. Piccirillo, C. Francesca, G. Bellieni, A. J. Melfi, J. B. Nyobe and J. N'ni, "Silicic Magmas from the Continental Cameroon Volcanic Line (Oku, Bambouto and Ngaoundéré): ${ }^{40} \mathrm{Ar} /{ }^{39} \mathrm{Ar}$ Dates, Petrology, Sr-Nd-O Isotopes and Their Petrogenetic Significance," Contribution to Mineralogy and Petrology, Vol. 135, No. 2-3, 1999, pp. 133-150. doi:10.1007/s004100050502

[4] IUSS Working Group WRB, "World Reference Base for Soil Resources 2006," World Soil Resources Reports No. 103. FAO, Rome, 2006.

[5] P. Tematio, L. Kengni, D. Bitom, M. Hodson, J. C. Fopoussi, O. Leumbe, H. G. Mpakam and D. Tsozué, "Soils and their Distribution on Bambouto Volcanic Mountain, West Cameroon Highland, Central Africa," Journal of African Earth Science, Vol. 39, No. 3-5, 2004, pp. 447-457. doi:10.1016/i.jafrearsci.2004.07.020

[6] P. Tematio, E. Fritsch, M. E. Hodson, Y. Lucas, D. Bitom and P. Bilong, "Mineral and Geochemical Characterization of a Leptic Aluandic Soil and a Thapto Aluandic-Ferralsol Developed on Trachytes in Mount Bambouto (Cameroon Volcanic Line)," Geoderma, Vol. 152, No. 3-4, 2009, pp. 314-323. doi:10.1016/j.geoderma.2009.05.029

[7] M. Doubé, "Pedogenesis, Classification and Charge Properties of the Bambouto Soil Sequence (West-Cameroon)," Ph.D. These, State University of Ghent, Belgium, 1989.

[8] D. Youmen, H.-U. Schmincke, J. Lissom and J. Etame, "Données Géochronologiques: Mise en Evidence des Différentes Phases Volcaniques au Miocène dans les Monts Bambouto (Ligne du Cameroun)," Sciences, Technologie et Développement, Vol. 11, 2005, pp. 49-57.

[9] S. Shoji, M. Nanzyo and R. A. Dahlgren, "Volcanic Ash 
Soils. Genesis, Properties and Utilization. (Developments in Soil Science Vol. 21)," Elsevier, Amsterdam, 1993.

[10] FAO, "World Soil Resources Report No. 94: Major Soils of the World," FAO, Rome, 2001.

[11] P. Tematio, "Etude Cartographique et Pétrographique des Sols à Caractères Ferrallitiques et Andosoliques dans les Monts Bambouto (Ouest Cameroun): Influence de la Nature Lithologique et des Facteurs du Milieu sur la Nature et la Distribution des Sols en Régions de Montagne Tropicale Humide," Ph.D. Thesis, Université de Yaoundé I, Yaoundé, 2005.

[12] B. P. K. Yerima and E. Van Ranst, "Major Soil Classification System Used in the Tropics: Soils of Cameroon," Trafford Publication, Victoria, 2005.

[13] A. K. Dongmo, D. Nkouathio, A. Pouclet, J. M. Bardintzeff, P. Wandji, A. Nono and H. Guillou, "The Discovery of Late Quaternary Basalt on Mount Bambouto: Implications for Recent Widespread Volcanic Activity in the Southern Cameroon Line," Journal of African Earth Science, Vol. 57, No. 1-2, 2010, pp. 96-108. doi:10.1016/i.jafrearsci.2009.07.015

[14] Y. Lucas, F. J. Luizao, A. Chauvel, J. Rouillet and D. Nahon, "The Relation between Biological Activity of the Rainforest and the Mineral Composition of Soils," Sciences, Vol. 260, No. 5107, 1993, pp. 521-523. doi:10.1126/science.260.5107.521

[15] D. Aran, M. Gury and E. Jeanroy, "Organo-Metallic Complexes in an Andosol: A Comparative Study with a Cambisol and Podzol," Geoderma, Vol. 99, No. 1-2, 2001, pp. 65-79. doi:10.1016/S0016-7061(00)00064-1

[16] R. Maignien, "Manuel pour la Description des Sols sur le Terrain," Document ORSTOM, Paris, 1980.

[17] R. A. Dahlgren, "Quantification of Allophane and Imogolite,” In: J. E. Amonette and L. W. Zelazny, Eds., Quantitative Methods in Soil Mineralogy, Soil Sciences Society of America, 1994, pp. 430-451.

[18] J. Poulenard and A. J. Herbillon, "Sur l'Existence de Trois Catégories d'Horizons de Référence dans les Andosols," Comptes Rendus de l'Académie des Sciences, Série 2331, 2000, pp. 651-657.

[19] C. W. Childs, N. Matsue and N. Yoshinaga, "Ferrihydrite in Volcanic Ash Soils of Japan," Soil Science and Plant Nutrition, Vol. 37, No. 2, 1991, pp. 299-311.

[20] R. John and V. B. Asio, "Soils of the Tropical Forests of Leyte, Philippines. I. Weathering, Soil Characteristics, Classification, and Site Qualities," In: A. Schulte and D. Ruhiyat, Eds., Soils of Tropical Forest Ecosystems, Springer, Berlin, 1998, pp. 29-36.

[21] K. A. Rahn and R. J. Mc Cafrfrey, "Compositional Differences between Arctic Aerosol and Snow," Nature, Vol. 280, No. 1, 1979, pp. 479-480. doi:10.1038/280479a0

[22] J. A. Herbillon, "Chemical Estimation of Weatherable Minerals Present in the Diagnostic Horizons of Low Activity Clay Soils," Proceeding of the 8th International Soil Classification Workshop, Rio de Janeiro, 12-23 May 1986, pp. 39-48.

[23] H. W. Nesbitt and G. M. Young, "Early Proterozoic Climates and Plate Motions Inferred from Major Element
Chemistry of Lutites," Nature, Vol. 279, 1982, pp. 715-717. doi:10.1038/299715a0

[24] T. Y. Irfan, "Mineralogy, Fabric Properties and Classification of Weathered Granites in Hong Kong," Quarterly Journal of Engineering Geology and Hydrogeology, Vol. 29, 1996, pp. 5-35. doi:10.1144/GSL.QJEGH.1996.029.P1.02

[25] K. Yonebayashi and T. Hattori, "Chemical and Biological Studies on Environmental Humic Acids. I. Composition of Elemental and Functional Groups of Humic Acids," Soil Science and Plant Nutrition, Vol. 34, No. 4, 1988, pp. 571-584.

[26] B. Prévosto, E. Dambrine, C. Moares and T. Curt, "Effects of Volcanic Ash Chemistry and Former Agricultural Use on the Soils and Vegetation of Naturally Regenerated Woodlands in the Massif Central, France," Catena, Vol. 56, No. 1-3, 2004, pp. 239-261.

doi:10.1016/j.catena.2003.10.014

[27] C. Mizota and L. P. Van Reenwijk, "Clay Mineralogy and Chemistry of Soils Formed in Volcanic Material in Diverse Climatic Regions," Soil Monography, Vol. 2, ISRIC, Wageningen, 1989.

[28] K. Wada and M. E. Harward, "Amorphous Clay Constituents of Soils," Advances in Agronomy, Vol. 26, 1974, pp. 211-260. doi:10.1016/S0065-2113(08)60872-X

[29] P. Violante and M. J. Wilson, "Mineralogy of Some Italian Andosols with Special Reference to the Origin of the Clay Fraction," Geoderma, Vol. 29, No. 2, 1983, pp. 157 174. doi:10.1016/0016-7061(83)90039-3

[30] A. G. Jongmans, P. Verburg, A. Nieuwenhuyse and F. Van Oort, "Allophane, Imogolite and Gibbsite in Coatings in Costa Rican Andisols," Geoderma, Vol. 64, No. 3-4, 1995, pp. 327-342. doi:10.1016/0016-7061(94)00015-3

[31] S. Ndayiragije and B. Delvaux, "Co-Existence of Allophane, Gibbsite, Kaolinite and Hydroxyl-Al-Interlayered 2:1 Clay Minerals in a Perudic Andosol," Geoderma, Vol. 117, No. 3-4, 2003, pp. 203-214. doi:10.1016/S0016-7061(03)00123-X

[32] D. Aran, M. Gury, M. Zida, E. Jeanroy and A. J. Herbillon, "Influence de la Roche-Mère et du Climat sur les Propriétés Andiques des Sols en Région Montagnarde Tempéré (Vosges, France)," European Journal of Soil Science, Vol. 49, No. 2, 1998, pp. 269-281. doi:10.1046/j.1365-2389.1998.00148.x

[33] R. L. Parfitt and J. M. Kimble, "Conditions for Formation of Allophane in Soils," Soil Science Society American Journal, Vol. 53, No. 3, 1989, pp. 971-977. doi:10.2136/sssaj1989.03615995005300030057x

[34] C. M. Fedo, H. W. Nesbitt and G. M. Young, "Unravelling the Effect of Potassium Metasomatism in Sedimentary Rocks and Paleosols with Implications for Paleoweathering Conditions and Provenance," Geology, Vol. 23, No. 10, 1995, pp. 921-924. doi:10.1130/0091-7613(1995)023<0921:UTEOPM>2.3.CO;2

[35] M. Tsalefac, "Variabilité Climatique, Crise Economique et Dynamique des Milieux Agraires sur les Hautes Terres de l'Ouest," Ph.D. Thesis, Université de Yaoundé I, Yaoundé, 1999. 